\title{
Isolation, Biosynthesis and Chemical Modifications of Rubterolones A-F, Rare Tropolone Alkaloids from Actinomadura
}

\author{
sp. 5-2
}

\author{
Huijuan Guo, ${ }^{\ddagger[a]}$ René Benndorf, ${ }^{\ddagger[a]}$ Daniel Leichnitz, ${ }^{[a]}$ Jonathan L. Klassen, ${ }^{[b]}$ John Vollmers, ${ }^{[c]}$ Helmar \\ Görls, ${ }^{[\mathrm{d}]}$ Matthias Steinacker, ${ }^{[\mathrm{a}]}$ Christiane Weigel, ${ }^{[\mathrm{a}]}$ Hans-Martin Dahse,${ }^{\left[{ }^{[a]}\right.}$ Anne-Kristin Kaster, ${ }^{[\mathrm{c}]} \mathrm{Z}$. \\ Wilhelm de Beer, ${ }^{[\mathrm{e}]}$ Michael Poulsen,${ }^{[\mathrm{f}]}$ and Christine Beemelmanns ${ }^{[\mathrm{a}]^{*}}$
}

\begin{abstract}
We report the discovery of six new highly substituted tropolone alkaloids, rubterolones A-F, from Actinomadura sp. 5-2, isolated from the gut of the fungus-growing termite Macrotermes natalensis. Rubterolones were identified using fungus-bacteria challenge assays and a HRMS-based dereplication strategy, and characterized by NMR and HRMS analyses and X-ray crystallography. Feeding experiments and subsequent chemical derivatisation led to a first library of rubterolones derivatives (A-L). Genome sequencing and comparative analyses revealed their putative biosynthetic pathway, which was supported by feeding experiments. This study highlights how gut microbes can present a prolific source of secondary metabolites.
\end{abstract}

\section{Introduction}

The rapid development of metabolomic ${ }^{1}$ and genomic technologies ${ }^{2}$ in the last decade has enabled a renaissance of natural product research. ${ }^{3}$ The combination of these techniques allows chemical mapping of interactions during host-microbe symbioses in high-throughput and on a molecular level. Structurally diverse secondary metabolites are often involved in these interactions, and have likely been evolutionarily selected for their bioactivities, ${ }^{4}$ thus making them promising

[a] Dr. Christine Beemelmanns, Leibniz Institute for Natural Product Research and Infection Biology - Hans Knöll Institute, Beutenbergstraße 11a, D-07745 Jena, Germany, Christine.beemelmanns@hki-jena.de

[a] Dr. Huijuan Guo, René Benndorf, Daniel Leichnitz, Matthias Steinacker, Christiane Weigel, Hans-Martin Dahse, Leibniz Institute for Natural Product Research and Infection BiologyHans Knöll Institute, Beutenbergstraße 11a, D-07745 Jena, Germany,

[b] Jonathan L. Klassen, Molecular \& Cell Biology, University of Connecticut, 91 North Eagleville Road, Storrs, CT 06269-3125, United States of America

[c] John Vollmers, Anne-Kristin Kaster, Leibniz Institute DSMZ, German Collection of Microorganisms and Cell Cultures, Inhoffenstraße 7B, 38124 Braunschweig, Germany

[d] Helmar Görls, Institute of Inorganic and Analytical Chemistry, Friedrich-Schiller-University Jena, Lessingstraße 8, D-07743 Jena, Germany

[e] Wilhelm de Beer, Department of Microbiology and Plant Pathology, Forestry and Agriculture Biotechnology Institute, University of Pretoria, Pretoria, South Africa

[f] Michael Poulsen, Centre for Social Evolution, University of Copenhagen, 2100 Copenhagen East, Denmark

‡ Shared first co-authorship.

Supporting information for this article is given via a link at the end of the document. pharmaceutical drug candidates. In recent years, protective bacterial symbionts of farming insects have attracted substantial attention amongst natural product chemists. ${ }^{5}$ The analysis of some of these symbionts has already uncovered an impressive amount of highly bioactive natural products, including the depsipeptide dentigerumycin from a fungus-growing ant symbiont $^{6}{ }^{6}$ and the polyene peroxide mycangimycin ${ }^{7}$ and macrolactam frontalamides ${ }^{8}$ from a symbiont of the southern pine beetle. Similarly, we and others have recently analyzed bacteria associated with the fungus-growing termite Macrotermes natalensis. ${ }^{9}$ This led to the discovery of the known putatively defensive metabolite bacillaene $A,{ }^{10}$ the NRPSderived microtermolides, ${ }^{11}$ the PKS-derived geldanamycinanalog natalamycin, ${ }^{12}$ and the newly reported macrotermycins. ${ }^{13}$ As termite workers are responsible for the construction of the fungus garden using fecal deposits of predigested plant material, gut bacteria are considered important for garden homeostasis. ${ }^{14}$ In this study, we focused on Actinomadura sp. 5-2 (RB29), isolated from the gut of a $M$. natalensis workers. Growth studies and activity-based dereplication indicated the production of potentially novel bioactive natural products. We used comparative metabolomics, ${ }^{13} \mathrm{C}$ isotope labelling, genomics, and $\mathrm{X}$-ray crystallography to characterize the new tropolone natural products, which we named rubterolones.

\section{Results and Discussion}

Five sterile termite workers were dissected, intact termite guts removed and prepared for the cultivation of bacteria. Six isolates with Actinobacteria-like morphollogy were chosen for further studies. After cultivation in ISP2 medium (seven days, $30{ }^{\circ} \mathrm{C}$, $150 \mathrm{rpm}$ ), metabolites were extracted using an established solid phase extraction procedure (see Supporting Information). Stock solutions of metabolite extracts $(1 \mathrm{mg} / \mathrm{mL})$ were assayed for antimicrobial activity against microbial human-pathogens (see: Supporting Information). Of the six tested strains, only strain 5-2 (RB29) displayed weak antimicrobial activity against Grampositive B. subtilis. Phylogenetic analysis allowed the assignment as Actinomadura sp. 5-2 (RB29) [KY312019] based on $100 \%$ homology to the $16 \mathrm{~S}$ rRNA gene of Actinomadura sp. GKU822 [KF638418.1]. 

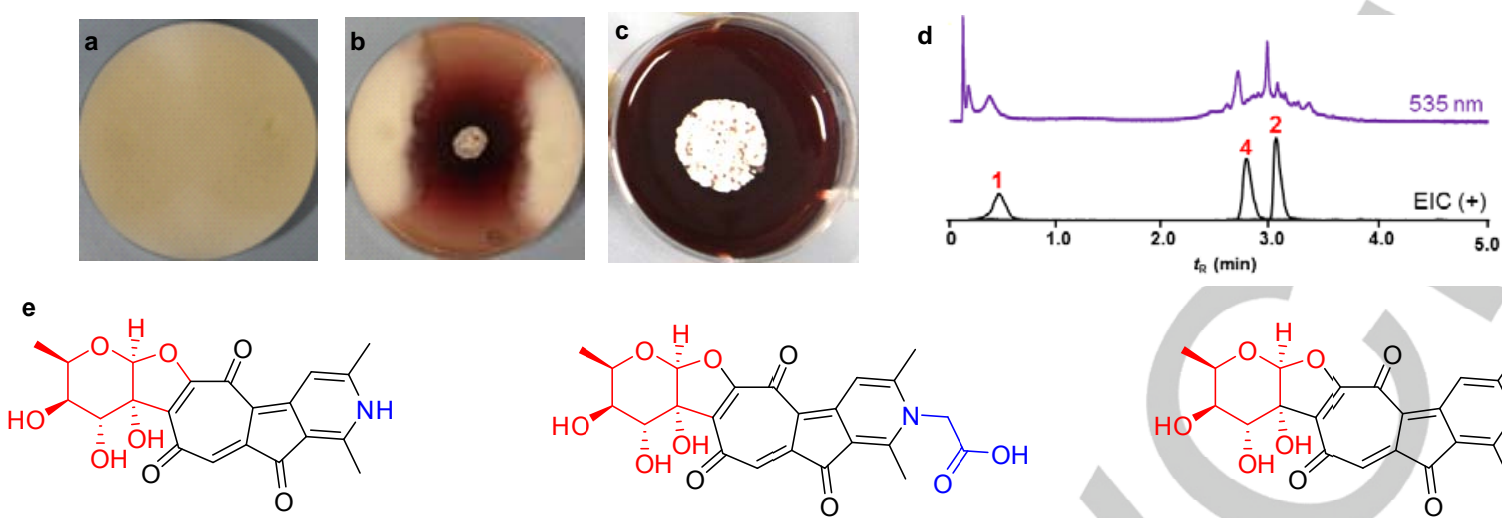

rubterolone $\mathrm{A}(\mathbf{1})$

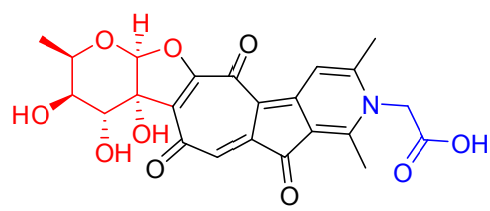

rubterolone $\mathrm{C}(3)$

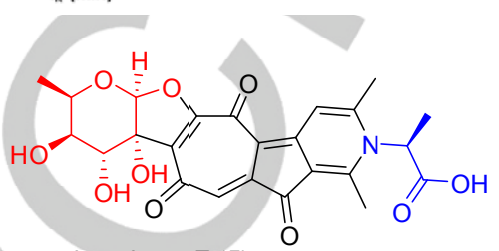

rubterolone $E(\mathbf{5})$

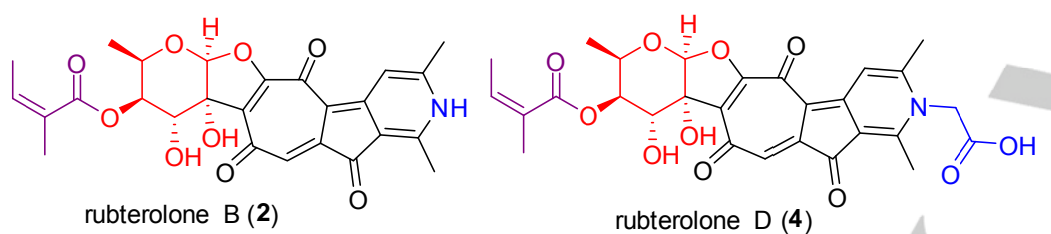

ubterolone B (2) rubterolone $\mathrm{D}(\mathbf{4})$<smiles></smiles><smiles></smiles>

isarubrolone $\mathrm{A}(\mathbf{8})$<smiles>CCOC(=O)OCCOCCO</smiles>

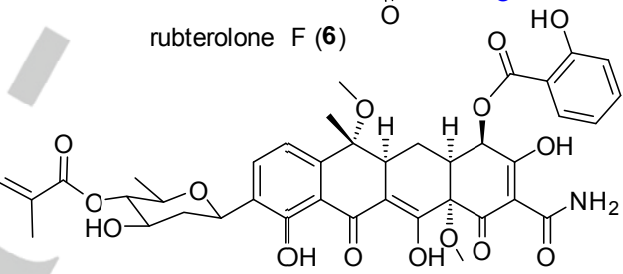

tetracycline SF2575 (9)

Figure 1. a-c) Activity assays: a) negative control Trichoderma sp. \#22, b) interaction assay Actinomadura sp. 5-2 (middle) against Trichoderma sp. \#22 (edge of plate); c) negative control Actinomadura sp. 5-2; d) representative UHPLC-MS analysis $(535 \mathrm{~nm})$ of zone of inhibition extracts: (EIC (+) of rubterolones A, B, D (1, 2, 4) at: $m / z 414.1(\mathbf{1}), 496.1$ (2), and 554.1 (4); e) structures of isolated rubterolones A-F (1-6), structural homologs rubrolone $A$ and isarubrolone $A(7,8)$ and tetracycline SF2575 (9).

To trigger the activation of otherwise silent gene clusters and the production of antimicrobial secondary metabolites, ${ }^{15}$ we then performed fungus-bacteria paired activity assays of strain 5-2 (RB29) against several fungal isolates from termite nests including the termites' food fungus. Upon co-cultivation, strain 52 exhibited moderate to good antifungal activity against several isolates, including the termite fungal cultivar. During growth and challenging assays, we discovered that this strain produces compounds that show distinct $\lambda_{\max }$ at $\sim 420 \mathrm{~nm}$ and $\sim 535 \mathrm{~nm}$, typical for conjugated (hetero)aromatic compounds. To analyze the respective metabolites, assay plates were extracted with methanol and analyzed by LC-HRMS. HRMS-based dereplication was performed using AntiBase ${ }^{16}$ and SciFinder, ${ }^{17}$ which revealed two so far not reported quasi-molecular ions at $\mathrm{m} / \mathrm{z} 414.1179$ and 496.1596 , each of which correlated with a characteristic UV absorption.

To obtain sufficient material for structure elucidation, we performed a larger scale plate cultivation (100 ISP-2 agar plates, $\mathrm{pH} 6$, ten days at $30{ }^{\circ} \mathrm{C}$ ), and applied an established work-up and prepurification procedure (see Supporting Information). ${ }^{12,13}$ Metabolite fractions containing the target ions were subjected to repetitive semi-preparative $\mathrm{C} 18$ reverse-phase HPLC using a
Phenomenex $\mathrm{C} 18$ column yielding compounds 1-2 as purple solids (1.5-2.5 mg/L) (Fig.1).

${ }^{1} \mathrm{H}$ and ${ }^{13} \mathrm{C}$ NMR analysis of compound $1\left(\mathrm{~m} / \mathrm{z} 414.1179[\mathrm{M}+\mathrm{H}]^{+}\right.$, $\mathrm{C}_{21} \mathrm{H}_{20} \mathrm{O}_{8} \mathrm{~N}$ ) revealed 21 carbon and 19 unique proton signals. Three methyl groups, four oxygenated aliphatic methines, two aromatic methines, one oxygenated quaternary carbon, and 11 $\mathrm{sp}^{2}$ quaternary carbons (including three carbonyl groups) could be assigned. This allowed the partial identification of a carbohydrate fragment. We next sought to determine the attached highly-substituted ring system by ${ }^{13} \mathrm{C}-{ }^{13} \mathrm{C} 2 \mathrm{D}$ NMR measurements. Therefore, we pursued ${ }^{13} \mathrm{C}$-acetate feeding experiments using a minimal medium supplemented with ${ }^{13} \mathrm{C}$ acetate. We were able to obtain ${ }^{13} \mathrm{C}$-enriched compound 1 for ${ }^{13} \mathrm{C}-{ }^{13} \mathrm{C}$ 2D INADEQUATE NMR analyses, which allowed for planar structure determination. The ${ }^{13} \mathrm{C}$-acetate feeding experiments demonstrate that 1 originates from PKS chemistry and includes oxidative rearrangements. ${ }^{18}$ The stereochemistry of 1 was deduced from NOE correlations, comparison of optical rotation, comparative biosynthetic pathway analysis, and finally proven by X-ray diffraction analysis (Fig. 2a). We named compound 1 rubterolone $A$ based on its red-purple colour and its resemblance to the known rubrolones $(7) .^{18}$ 
a

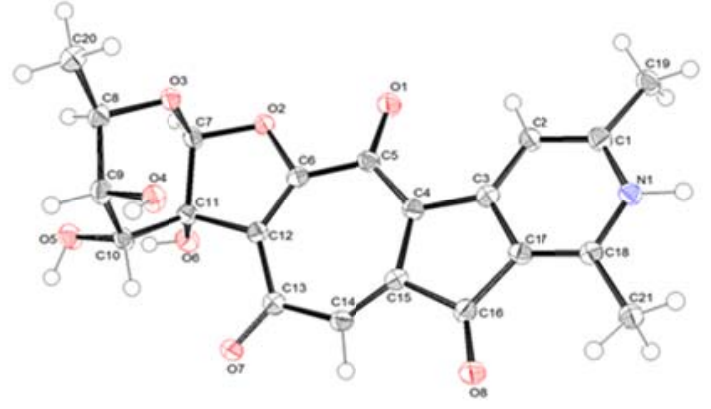

b

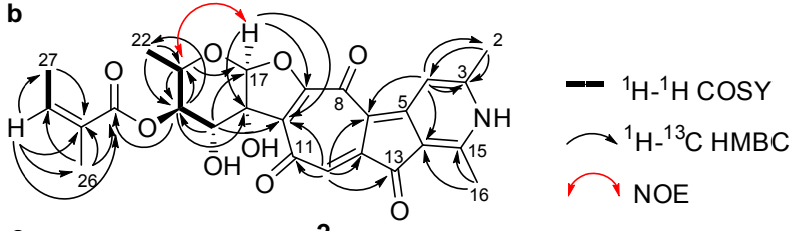

c

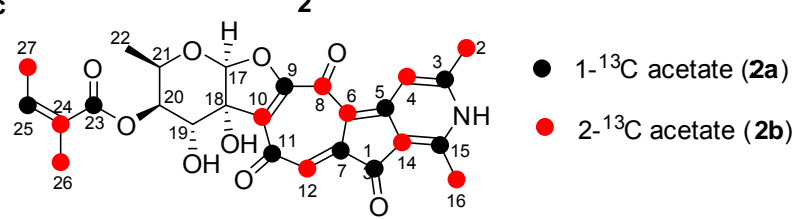

Figure 2. a) ORTEP plot of crystal structure of rubterolone A (1) with displacement ellipsoids of non-hydrogen atoms drawn at $50 \%$ probability level b) key COSY, HMBC and NOE correlations and c) ${ }^{13} \mathrm{C}$-acetate labeling pattern of rubterolone $B(\mathbf{2} \mathbf{a}, \mathbf{2} \mathbf{b})$.

Compound 2 (rubterolone $\mathrm{B}, \mathrm{m} / \mathrm{z} 496.1596[\mathrm{M}+\mathrm{H}]^{+}, \mathrm{C}_{26} \mathrm{H}_{26} \mathrm{O}_{9} \mathrm{~N}$ ) exhibited a very similar ${ }^{1} \mathrm{H}$ NMR, ${ }^{13} \mathrm{C} N M R$, and UV spectrum to 1, verifying their structural similarity. Comparative $2 \mathrm{D} N M R$ revealed two additional methyl groups, two olefinic carbons, and a carbonyl group together comprising an angelic ester at position C-20. The stereochemistry of $\mathbf{2}$ was established by comparative NMR analysis, NOESY and 1D selective NOE experiments as well as ${ }^{13} \mathrm{C}-{ }^{13} \mathrm{C}$ 2D INADEQUATE NMR (Fig. 2b, and see Supporting Information). Studying different growth conditions indicated that addition of amino acids enhanced the production of rubterolone derivatives (Fig. 3, Table 1). Using modified minimal media, we were able to isolate and completely characterize derivatives 3-6, which carry a $N$-substituted pyridine moiety. Interestingly, we also detected compound 4 using standard cultivation conditions, most likely due to high glycine concentrations in the cellular or culture environment. Structures of all derivatives were solved by comparative $1 \mathrm{D}$ and 2D NMR analysis, HRMS, UV-Vis and IR analysis.

Furthermore, HRMS analysis of enriched compound fractions, obtained from feeding experiments with $\beta$-alanine and L-lysine, indicated the formation of derivatives 10-15. Both amine groups of L-lysine react and form the respective pyridine ring (Table 1). The newly isolated rubterolones belong to the rare class of tropolone-containing natural products, which have only recently received scientific attention. ${ }^{18-21}$ The first bacterial-derived tropolone alkaloid, rubrolone A (7) was already reported in 1978 from Streptomyces enchinoruber, ${ }^{22}$ but it took nearly 40 years until rubrolones B-D were identified and a putative biosynthetic pathway proposed. ${ }^{18}$ Rubterolones share the same fused

pentacyclic core ring system as rubrolones, which consists of a relatively rare seven-membered aromatic tropolone ring fused to a sugar moiety and a five-membered cyclopentanone attached to a highly substituted pyridine moiety. The conjugated ring system allows rapid keto-enol tautomerization resulting in a $\mathrm{pH}$ and solvent dependent colour change (Fig. 3). ${ }^{18}$ Unlike rubrolone, rubterolones are derived from the deoxysugar 6-deoxy-gulose (inverted stereochemistry at C-19), and carry an additional angelic acid modification at position C-20. Furthermore, the pyridine moiety is substituted with two methyl substituents ( $C-2$, $\mathrm{C}-16)$ instead of a propyl chain. These structural features indicated a diverging biosynthetic origin from rubrolone (7) and the recently reported isarubrolones (8).

Table 1. Structures of isolated rubterolone derivatives 1-6, 10-15 obtained from feeding experiments.

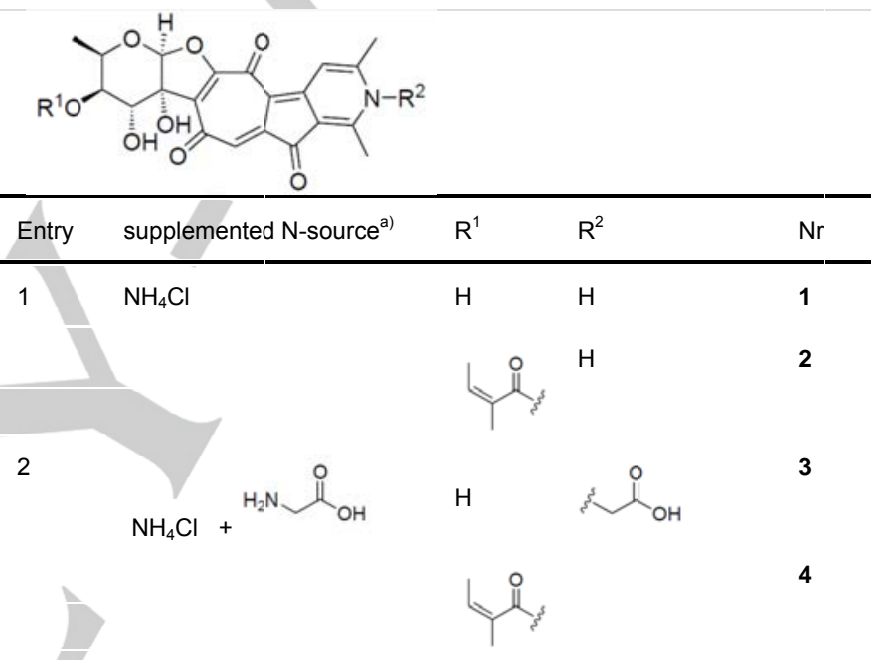

3

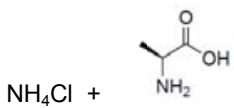<smiles>NCCC(=O)O</smiles>

$\mathrm{H}$<smiles>CCCCC(=O)O</smiles><smiles>C/C=C(/C)C(=O)CCC</smiles>

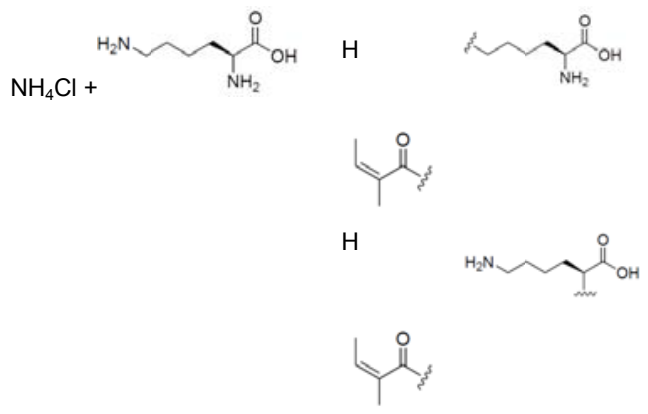

a) Minimal medium supplemented with $25 \mathrm{mM}$ amino acid (see: Supporting Information) 


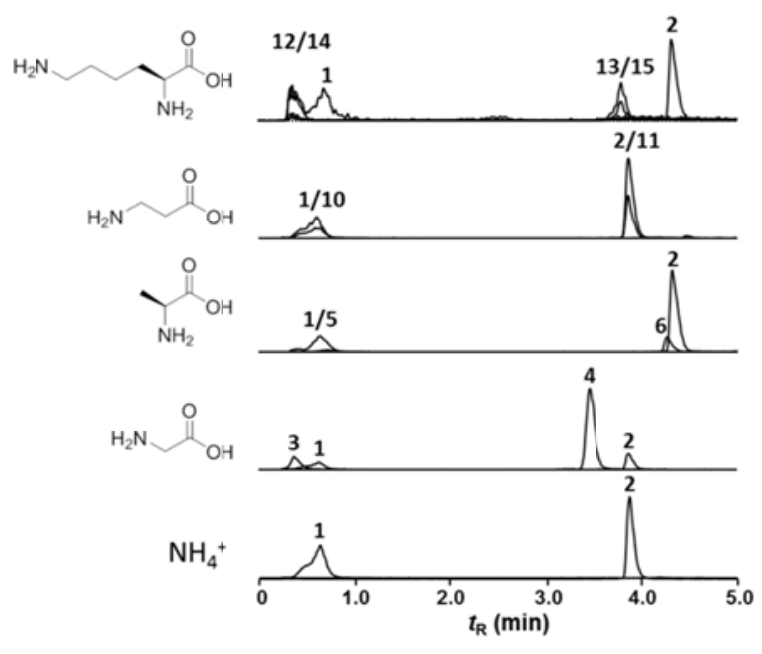

Figure 3. UHPLC-MS analysis of amine feeding experiments using selected ion mode EIC (+) of rubterolones A-L (1--6, 10--15 as $\left.[\mathrm{M}+\mathrm{H}]^{+}\right)$.

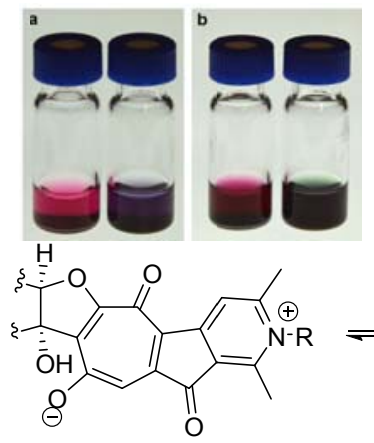

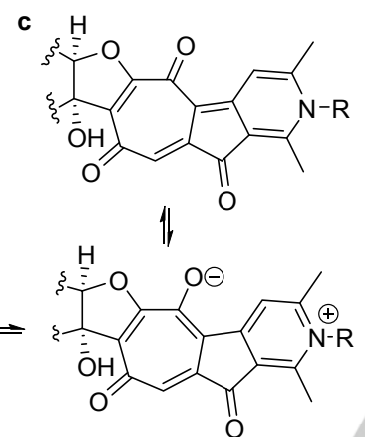

Figure 4. a) Solutions of rubterolone A (1) in methanol (left) and DMSO (right); b) solutions of rubterolone D (4) in methanol (left) and DMSO (right); c) generalized drawing of possible tautomeric forms.

We then investigated whether rubterolones could be chemically modified for future applications, and we were delighted to find that it was possible to modify compound $\mathbf{2}$ selectively at position C-19 (Fig. 5). More importantly, the glycine moiety at N1 was selectively coupled with propargyl amine to give $\mathbf{4 a}$, which could again serve as starting compound for Click chemistry.
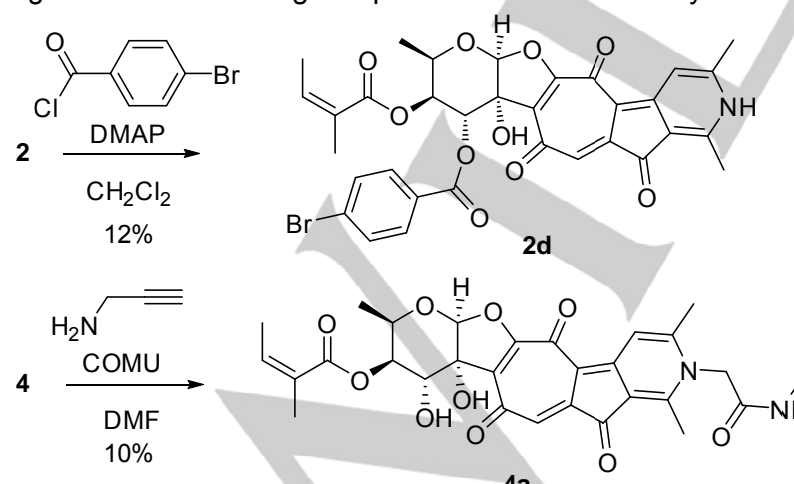

$4 a$
Rubterolones exhibited no significant antifungal activity, and were therefore not responsible for the observed antifungal activity in our co-cultivation assay. However, less polar fractions of co-culture extracts, from which 1-3 were isolated, contain metabolites that exhibit antimicrobial activities and are topic of current isolation efforts.

To gain more information about the biosynthetic pathway of rubterolones, we sequenced the genome of Actinomadura sp. 5-2 on an Illumina MiSeq using paired-end v3 chemistry (300 cycles per read). The genome was assembled using SPAdes v.3.6.2, ${ }^{23}$ and annotated using Prokka v1.11. ${ }^{24,25}$ Secondary metabolism-related functions were predicted using antiSMASH, ${ }^{26}$ which identified a putative type II PKS biosynthetic gene cluster with partial sequence similarity to the recently reported rubrolone $(r u b)$ and isatropolone (ist) cluster, ${ }^{18}$ albeit with substantial gene order rearrangement (Fig. 6a). The putative biosynthetic gene cluster $(r b /)$ encodes 23 proteins (24,607 bp) annotated as RblA-W (Fig. 6, see: Supporting Information). The gene cluster contains all necessary elements for the biosynthesis of the polyketide core structure, enzymes for the putative biosynthesis of 2-keto-6-deoxy-D-gulose, several modifying enzymes, and flanking transcriptional regulators (see Supporting Information).

In short, we propose that the PKS-derived intermediate $\mathbf{1 6}$ is biosynthesized by an enzymatic cascade involving RblO, RbIP, $\mathrm{RbIQ}, \mathrm{RbIS}$ and the polyketide cyclase RbIU. The enzymes RbIB, $\mathrm{RbIC}$, and RbIV presumably catalyze the oxidation, cyclization, rearrangement and decarboxylation of the polyketide core to produce intermediate $\mathbf{1 7}$, which spontaneously forms a pyridine by abiotically capturing ammonium or other primary aminecontaining compounds (Table 1$)^{118}$. Subsequent oxidation by the oxidoreductase RbIL results in the rubterolone aglycone core structure 18, to which d-TDP-2-keto-6-deoxy-D-gulose is then added by Rbll.

It is important to note that the timing of pyridine formation and glycosylation, and whether the necessary aldol reaction occurs enzymatically or spontaneous, remains speculative. Compounds of type 1 can then be further modified by the addition of angelic$\mathrm{CoA}$ at $\mathrm{C}-20$. We speculate that RblO might be responsible for this process because of its weak homology to SsfG, which performs this step during SF2575 (9) biosynthesis. Although the biosynthesis of the angelic moiety itself remains unclear, the significant homology of RbIA and RbID to SsfE and SsfN, respectively, suggests a similar biiosynthetic pathway. ${ }^{27}$

\section{Conclusions}

Our report demonstrates that ecological profiling of microbial isolates from the fungus-growing termite system is a highly efficient approach to harvest the enormous biosynthetic potential of microbial symbionts. Growth studies and chemical analysis of Actinomadura sp. 5-2 led to the isolation of several novel tropolone alkaloids named rubterolones.

Figure 5. Chemical modifications of rubterolone B (2) and D (4). 
a)

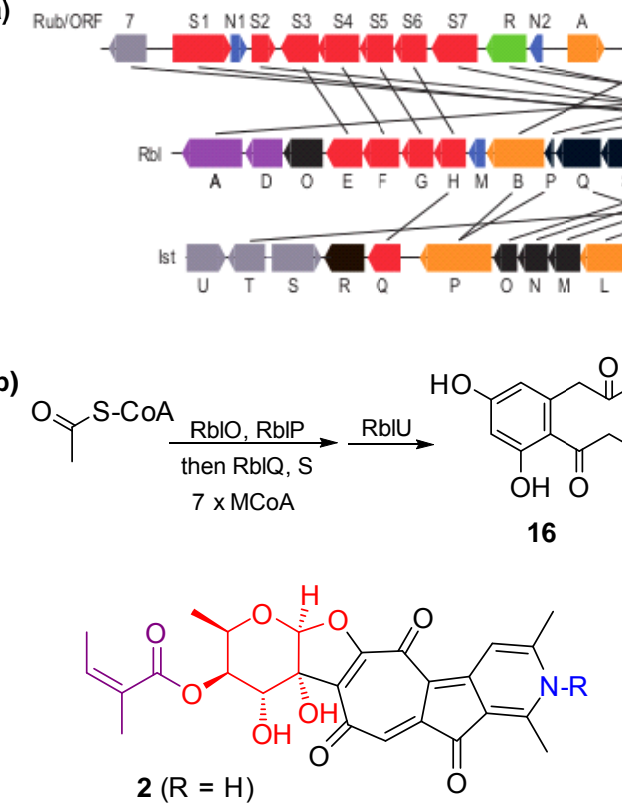

B

$\begin{array}{llllll}C & \text { E1 E2 E3 E4 E5 E6 E7 E8 } & \text { E9 } & 30 & 31 & 32\end{array}$

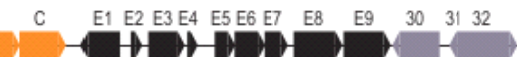

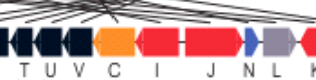

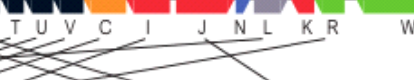
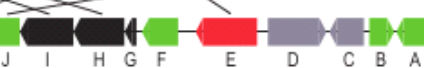

S-ACP

$\underset{\mathrm{RbIC}, \mathrm{RbIV}}{\stackrel{\mathrm{RblB}}{\longrightarrow}}$

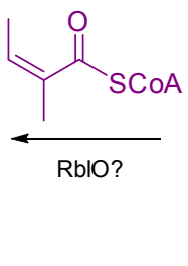

17<smiles>[R]N1C(C)=CC2=C3C(=O)C4=C(C(=O)C=C3C(=O)C2=C1C)[C@@]1(O)[C@@H](O)[C@@H](O)[C@@H](C)O[C@@H]1O4</smiles>

$1(\mathrm{R}=\mathrm{H})$
Angelic acid biosynthesis

Polyketide biosynthesis

Sugar biosynthesis

Uncertain function

Oxygenases

Regulation

Figure 6. a) Comparative gene maps of $r u b, r b /$ and ist biosynthetic clusters and b) proposed biosynthesis pathway of rubterolones ( $r b l)$

to $250{ }^{\circ} \mathrm{C}$ with an interface temperature of $350{ }^{\circ} \mathrm{C}$ and a heat block of $400{ }^{\circ} \mathrm{C}$. The nebulizing gas flow was set to $1.5 \mathrm{~L} / \mathrm{min}$ and dry gas flow to $15 \mathrm{~L} / \mathrm{min}$. Semi-preparative HPLC was performed on a Shimadzu HPLC system using a Phenomenex Luna C18(2) $250 \times 10 \mathrm{~mm}$ column (particle size $5 \mu \mathrm{m}$, pore diameter $100 \AA$ ). IR spectra were recorded on an FT/IR4100 ATR spectrometer (JASCO). Optical rotations were recorded in DMSO on a $\mathrm{P}-1020$ polarimeter (JASCO).

Bacterial isolation and cultivation: Five sterile termite workers were dissected. Intact termite guts were crushed in phosphate buffered saline and dilution series plated on chitin medium supplemented with $0.05 \mathrm{mg} / \mathrm{L}$ cycloheximide. Plates were incubated at $30^{\circ} \mathrm{C}$ for up to 14 days, and the observed six isolates with Actinobacteria-like morphology purified via subculture by cultivation in liquid ISP 2 media for five to seven days at $30{ }^{\circ} \mathrm{C}$.

Phylogenetic analysis: Six isolates were cultivated for seven days in liquid media ISP2 $\left(30^{\circ} \mathrm{C}, 150 \mathrm{rpm}\right)$. Cells were harvested, and genomic DNA was extracted using the GenJet Genomic DNA Purification Kit (Thermo Scientific, \#K0721) following the manufacturer's instructions with the following modifications: a) lyssozyme treatment was extended to $40 \mathrm{~min}$, and b) proteinase $\mathrm{K}$ treatment was extended to $40 \mathrm{~min}$. The $16 \mathrm{~S}$ rRNA gene was amplified using the primer set 1492R/27F. Amplification reactions were prepared in a $25 \mu \mathrm{L}$ final reaction volume containing $7.25 \mu \mathrm{L}$ distilled water, $5.0 \mu \mathrm{L}$ HF buffer, $5.0 \mu \mathrm{L}$ of each primer $(2.5 \mu \mathrm{M})$, $0.5 \mu \mathrm{L}$ dNTPs $(10 \mu \mathrm{M})$, and $0.25 \mu \mathrm{L}$ Phusion High Fidelity DNA Polymerase (New England Biolabs) and $2.0 \mu \mathrm{L}$ of extracted DNA (template). PCR was performed under the following conditions: $98{ }^{\circ} \mathrm{C} / 38$ $\mathrm{s}, 32$ cycles of $98{ }^{\circ} \mathrm{C} / 30 \mathrm{~s}, 52{ }^{\circ} \mathrm{C} / 45 \mathrm{~s}, 72{ }^{\circ} \mathrm{C} / 1 \mathrm{~min} 20 \mathrm{sec}$, and a final extension of $72^{\circ} \mathrm{C} / 8 \mathrm{~min}$. PCR products were separated by agarose gel electrophoresis. PCR reactions were purified using the PCR Purification Kit (Thermo Scientific). DNA fragments were sequenced at GATC (Konstanz). Resulting sequences were assessed for purity and mismatches using BioEdit. ${ }^{28}$ Forward and reverse sequences (GenBank accessions numbers KY312017-KY312022) of each sequence were 
assembled with BioEdit, tested for chimeras using DECIPHER, ${ }^{29}$ and used for a BLASTn search in GenBank. ${ }^{30}$

Genome sequencing: gDNA of isolate $5-2$ was sheared using a Covaris S220 sonication device (Covaris Inc; Massachusetts, USA) with the following settings: 55 s, 175 W, $5 \%$ Duty factor, 200 cycles of burst, 55.5 $\mu \mathrm{L}$ input volume. Sequencing libraries were prepared using the NEBNext ${ }^{\circ}$ Ultra ${ }^{\mathrm{TM}}$ DNA Library Prep Kit for Illumina ${ }^{\circledR}$ (New England Biolabs, Frankfurt, Germany) as per the manufacturer's instructions. The libraries were then sequenced on an Illumina ${ }^{\circledR}$ MiSeq machine using v3 chemistry and a paired-end approach (300 cycles each). Read processing and assembly: Raw sequences were subjected to adapte clipping and quality trimming using Trimmomatic. ${ }^{31}$ Processed reads were assembled withSPAdes v3.6.2. ${ }^{23}$ The quality as well as taxonomic placement of the assembled genome were assessed with checkM v1.0.4. ${ }^{32}$ Annotations were performed using Prokka v1.11. ${ }^{25}$ The genome draft sequence has been submitted to $\mathrm{NCBI}$ under project ID: PRJNA356838, sample-ID: SAMN06127924.

Antimicrobial activity assays: Isolated strains were cultivated in $50 \mathrm{~mL}$ ISP2 broth for seven days at $30{ }^{\circ} \mathrm{C}$ at $120 \mathrm{rpm}$. Each culture was separated into supernatant and cell pellet by centrifugation (4000 rpm, 10 min, RT). Cell pellet was lysed and extracted using $9 \mathrm{~mL} \mathrm{MeOH}$. Cell debris was removed by centrifugation (4000 rpm, $10 \mathrm{~min}$ ), and methanolic cell extracts $(\sim 9 \mathrm{~mL})$ were added to the previously separated culture supernatant. The combined crude extract was loaded on a preactivated and equilibrated C18 cartridge (500 mg C18, 20\% MeOH/80\% $\mathrm{ddH}_{2} \mathrm{O}$ ). The loaded SPE column was washed with $20 \% \mathrm{MeOH}$, and then eluted using $100 \% \mathrm{MeOH}$ and $100 \%$ acetone respectively. Both extracts were pooled and concentrated under reduced pressure. Finally, organic extract was dissolved with $100 \% \mathrm{MeOH}$ to yield a $1.0 \mathrm{mg} / \mathrm{mL}$ stock solution for LC-MS analysis and antimicrobial activity test.

Crystal structure determination: The intensity data were collected on a Nonius KappaCCD diffractometer, using graphite-monochromated Mo-K radiation. Data were corrected for Lorentz and polarization effects; absorption was taken into account on a semi-empirical basis using multiple-scans. The structure was solved by direct methods (SHELXS) and refined by full-matrix least squares techniques against $\mathrm{Fo}^{2}$ (SHELXL97). ${ }^{[3]}$ All hydrogen atoms (with exception of the water molecule O3W) were located by difference Fourier synthesis and refined isotropically. Crystal Data for rubterolone A: $\mathrm{C}_{21} \mathrm{H}_{22.5} \mathrm{NO}_{9.75}, \mathrm{Mr}=444.90 \mathrm{gmol}^{-1}$, redbrown prism, size $0.134 \times 0.044 \times 0.042 \mathrm{~mm}^{3}$, monoclinic, space group $\mathrm{C}$ $2, a=18.1189(8), b=14.5096(5), c=7.3114(3) \AA, \beta=93.922(2)^{\circ}, V=$ 1917.65(13) $\AA^{3}, \mathrm{~T}=-140{ }^{\circ} \mathrm{C}, \mathrm{Z}=4, \rho_{\text {calcd. }}=1.541 \mathrm{gcm}^{-3}, \mu\left(\mathrm{Mo}-\mathrm{K}_{\alpha}\right)=$ $1.23 \mathrm{~cm}^{-1}$, multi-scan, transmin: 0.6826 , transmax: $0.7456, F(000)=934$, 11572 reflections in $\mathrm{h}(-21 / 23), \mathrm{k}(-18 / 18), \mathrm{l}(-9 / 9)$, measured in the range $2.79^{\circ} \leq \Theta \leq 27.48^{\circ}$, completeness $\Theta \max =99.6 \%, 4295$ independent reflections, $R_{\text {int }}=0.0296,3881$ reflections with $F_{o}>4 \sigma\left(F_{0}\right), 378$ parameters, 1 restraints, $\mathrm{R} 1_{\mathrm{obs}}=0.0392, \mathrm{wR}^{2}{ }_{\mathrm{obs}}=0.0794, \mathrm{R} 1_{\mathrm{all}}=0.0481$, $\mathrm{wR}^{2}{ }_{\text {all }}=0.0850$, GOOF $=1.114$, Flack-parameter $0.4(8)$, largest difference peak and hole: $0.178 /-0.182$ e $\AA^{-3}$. Crystallographic data deposited at the Cambridge Crystallographic Data Centre under CCDC1524117 for rubterolone A contain the supplementary crystallographic data excluding structure factors; this data can be obtained free of charge via www.ccdc.cam.ac.uk/conts/retrieving.html (deposit@ccdc.cam.ac.uk).

Large-scale cultivation on plates: Cultivation was performed by inoculation of 100 ISP2 agar plates (standard $15 \mathrm{~mm}$ x $90 \mathrm{~mm}, 20 \mathrm{~mL}$ ISP2 agar/plate) at $30{ }^{\circ} \mathrm{C}$ for 10 days until strong production of red pigment was observed. Whole agar plates were cut into pieces and extracted twice with $2 \mathrm{~L} \mathrm{MeOH}$ at $4{ }^{\circ} \mathrm{C}$ overnight. $\mathrm{MeOH}$ extracts were filtered and concentrated under reduced pressure. The crude extract was dissolved using $10 \%$ aq. $\mathrm{MeOH}$, loaded on an activated and equilibrated
SPE C18 column $(10 \mathrm{~g})$, and fractionated by step-gradient from $10 \%$ $\mathrm{MeOH}$ to $100 \% \mathrm{MeOH}$ (100 mL each)). The eluent using $30 \% \mathrm{MeOH}$ was first purified by Sephadex LH20 using $50 \% \mathrm{MeOH}$ and further separated by semi-preparative reverse-phase HPLC to yield pure rubterolone A (1, $5.50 \mathrm{mg})$, rubterolone $\mathrm{B}(2,5.33 \mathrm{mg})$ and rubterolone $\mathrm{D}(4,3.25 \mathrm{mg})$.

Isotope labeling: Strain 5-2 was cultivated in ISP2 broth for a maximum of 10 days $\left(30^{\circ} \mathrm{C}, 120 \mathrm{rpm}, 50 \mathrm{~mL}\right)$. Biomass was separated from culture supernatant by centrifugation, washed twice and added to autoclaved minimal media $(1 \mathrm{~L})$ containing either $1-{ }^{13} \mathrm{C} \mathrm{CH}_{3} \mathrm{CO}_{2} \mathrm{Na}(400 \mathrm{mg} / \mathrm{L}), 2-{ }^{13} \mathrm{C}$ $\mathrm{CH}_{3} \mathrm{CO}_{2} \mathrm{Na}(400 \mathrm{mg} / \mathrm{L})$ or $1,2-{ }^{13} \mathrm{C}_{2} \mathrm{C}^{-} \mathrm{H}_{3} \mathrm{CO}_{2} \mathrm{Na}(200 \mathrm{mg} / \mathrm{L})+\mathrm{CH}_{3} \mathrm{CO}_{2} \mathrm{Na}$ $(200 \mathrm{mg} / \mathrm{L})$. After cultivation for 10 dlays $\left(30{ }^{\circ} \mathrm{C}, 120 \mathrm{rpm}\right)$, the reddish culture supernatant was mixed with activated HP20 resin $(20 \mathrm{~g} / \mathrm{L})$ and stirred at $4{ }^{\circ} \mathrm{C}$ overnight. The HP20 resin was separated by filtration, washed with dd $\mathrm{H}_{2} \mathrm{O}(1 \mathrm{~L})$ and eluterd using $\mathrm{MeOH}(1 \mathrm{~L})$. The resulting $\mathrm{MeOH}$ eluent was dried under reduced pressure, suspended in $10 \%$ $\mathrm{MeOH}$, loaded on a pre-activated and equilibrated SPE-C18 (2 g) cartridge and eluted using a step gradient to yield $30 \% \mathrm{MeOH}, 50 \%$ $\mathrm{MeOH}, 80 \% \mathrm{MeOH}$ and $100 \% \mathrm{MeOH}$ fractions respectively. The resulting $30 \%$ and $50 \% \mathrm{MeOH}$ extracts were submitted to semipreparative reverse-phase HPLC fractionation to yield the respective isotope-labeled compounds.

Amine feeding experiments and isolation of rubterolones C-L (3-6, 10-15): Bacteria were cultivated in ISIP2 broth for a maximum of 10 days $\left(30{ }^{\circ} \mathrm{C}, 120 \mathrm{rpm}, 50 \mathrm{~mL}\right)$. Biomass was separated from culture supernatant by centrifugation ( $6000 \mathrm{rpm}, \mathrm{RT})$, and washed twice and added to autoclaved minimal media supplemented with the respective amino acid (culture size: $2 \mathrm{~L}+25 \mathrm{mM}$ amino acid) respectively. The cultures were kept at $30^{\circ} \mathrm{C}$ for 10 days (120 rpm), then centrifuged and the supernatant separated from the ciell pellet. Activated HP20 resin (20 $\mathrm{g} / \mathrm{L}$ ) was added to the supernatant, and kept under stirring at $4{ }^{\circ} \mathrm{C}$ overnight. The HP20 resin was separated by filtration, washed with dd $\mathrm{H}_{2} \mathrm{O}(1 \mathrm{~L})$ and eluted using $\mathrm{MeOH}(1 \mathrm{~L})$. The resulting $\mathrm{MeOH}$ eluent was dried under reduced pressure, suspended in $10 \% \mathrm{MeOH}$, loaded on a pre-activated and equilibrated SP'E-C18 (2 g) cartridge and eluted using a step gradient to yield $10 \% \mathrm{MeOH}, 30 \% \mathrm{MeOH}, 50 \% \mathrm{MeOH}, 80 \%$ $\mathrm{MeOH}$ and $100 \% \mathrm{MeOH}$ fractions respectively. The SPE fractions containing the target ions were submitted to semi-preparative reversephase HPLC fractionation to yield the respective compounds $(3-6,10$ 15).

Rubterolone A (1): purple solid; [a] ${ }^{25}{ }_{\mathbb{D}}-149^{\circ}$ (c $0.004 \mathrm{w} / \mathrm{v} \%$, DMSO); UV (MeCN/H $\left.\mathrm{H}_{2} \mathrm{O} / \mathrm{FA}\right) \lambda_{\max } 216,275,424,535 \mathrm{~nm}$; IR (ATR) $\mathrm{v}_{\max } 3368,3256$, 2975, 2926, 2898, 1718, 1643, 1588, 1540, 1466, 1390, 1324, 1216, 1167, 1094, 1055, 1005, 943, 888, 854, 791, $762 \mathrm{~cm}^{-1}$; NMR data: see supporting information; ESI-HRMS $[\mathrm{M}+\mathrm{H}]^{+}$: 414.1179 (calcd for $\left.\mathrm{C}_{21} \mathrm{H}_{20} \mathrm{O}_{8} \mathrm{~N}: 414.1183\right)$.

Rubterolone B (2): purple solid; [a] ${ }^{25}{ }_{\mathbb{D}}-108^{\circ}$ (c $0.004 \mathrm{w} / \mathrm{v} \%$, DMSO); UV $\left(\mathrm{MeCN} / \mathrm{H}_{2} \mathrm{O} / \mathrm{FA}\right) \lambda_{\max }: 216,275,424,535 \mathrm{~nm}$; IR (ATR) $v_{\max }: 3398,3280$ 2929, 1711, 1644, 1588, 1550, 1428, 1388, 1324, 1264, 1144, 1104, 1054, 1027, 947, 890, 826, 793, $768 \mathrm{~cm}^{-1}$; NMR data: see supporting information; ESI-HRMS $[\mathrm{M}+\mathrm{H}]^{+}$: $\mathrm{m} / \mathbb{z} 496.1596$ (calcd for $\mathrm{C}_{26} \mathrm{H}_{26} \mathrm{O}{ }_{9} \mathrm{~N}$ : 496.1602).

4-Bromobenzoyl rubterolone B (2d): purple solid; UV (MeCN/ $\left.\mathrm{H}_{2} \mathrm{O} / \mathrm{FA}\right)$, $\lambda_{\max } 223,255,274,433,549 \mathrm{~nm}$; NMR data: see supporting information; ESI-HRMS $[\mathrm{M}+\mathrm{H}]^{+}$miz 678.0974 (calcd for $\mathrm{C}_{33} \mathrm{H}_{29} \mathrm{O}_{10} \mathrm{~N}^{79} \mathrm{Br}, 678.0969$ ).

Rubterolone C (3): purple solid; [ $\alpha]^{25}{ }_{\mathbb{D D}}-412^{\circ}$ (c $0.002 \mathrm{w} / \mathrm{v} \%$, DMSO); UV $\left(\mathrm{MeCN} / \mathrm{H}_{2} \mathrm{O} / \mathrm{FA}\right) \lambda_{\max } 216,273,430,535 \mathrm{~nm}$; IR (ATR) $\mathrm{v}_{\max } 3363,2934$, 1708, 1642, 1551, 1481, 1427, 1370, 1329, 1286, 1214, 1115, 1047, 997, 946, $910 \mathrm{~cm}^{-1}$; NMR data: Supporting Information; ESI-HRMS [M+H] $m / z 472.1229$ (calcd for $\mathrm{C}_{23} \mathrm{H}_{22} \mathrm{O}_{10} \mathrm{~N}, 472.1238$ ).

Rubterolone D (4): purple solid; [ $\alpha]^{25}{ }_{\mathrm{ID}}-412^{\circ}$ (c $0.002 \mathrm{w} / \mathrm{v} \%$, DMSO); UV $\left(\mathrm{MeCN} / \mathrm{H}_{2} \mathrm{O} / \mathrm{FA}\right) \lambda_{\max }: 216,275,424,535 \mathrm{~nm}$; IR (ATR) $\mathrm{v}_{\max }: 3385,2983$, 2932, 1710, 1636, 1598, 1556, 14810,1433, 1377, 1323, 1281, 1214 , 
1116, 1035, 992, 940, 896, $768 \mathrm{~cm}^{-1}$, NMR data: see Supporting Information; ESI-HRMS [M+H] $]^{+} \mathrm{m} / \mathrm{z} 554.1652$ (calcd for $\mathrm{C}_{28} \mathrm{H}_{28} \mathrm{O}_{11} \mathrm{~N}$ : 554.1657).

Propargyl-rubterolone D (4a): purple solid; UV (MeCN/ $\left.\mathrm{H}_{2} \mathrm{O} / \mathrm{FA}\right), \lambda_{\max }$ 228, 276, 437, $550 \mathrm{~nm}$; NMR data: see Supporting Information; ESIHRMS $[\mathrm{M}+\mathrm{H}]^{+} \mathrm{m} / \mathrm{z} 591.1968$ (calcd for $\mathrm{C}_{31} \mathrm{H}_{31} \mathrm{O}_{10} \mathrm{~N}_{2}, 591.1973$ ).

Rubterolone E (5): purple solid; [ $\alpha]^{25}-128$ (c $0.002 \mathrm{w} / \mathrm{v} \%$, DMSO); UV $\left(\mathrm{MeCN} / \mathrm{H}_{2} \mathrm{O} / \mathrm{FA}\right) \lambda_{\max } 221,276,430,536 \mathrm{~nm}$; IR (ATR) $\mathrm{V}_{\max } 3359,2983$, 2940, 1707, 1644, 1600, 1549, 1481, 1427, 1368, 1317, 1236, 1121, 1026, $899 \mathrm{~cm}^{-1}$; NMR data: see Supporting Information; ESI-HRMS $[\mathrm{M}+\mathrm{H}]^{+} \mathrm{m} / \mathrm{z} 486.1388$ (calcd for $\mathrm{C}_{24} \mathrm{H}_{24} \mathrm{O}_{10} \mathrm{~N}, 486.1395$ )

Rubterolone F (6): purple solid; [ a $^{25}{ }_{\mathrm{D}}-236$ (c $0.002 \mathrm{w} / \mathrm{v} \%$, DMSO); UV (MeCN/H $\left.\mathrm{H}_{2} \mathrm{O} / \mathrm{FA}\right) \lambda_{\max } 220,277,435,548 \mathrm{~nm}$; IR (ATR) $\mathrm{v}_{\max } 3414,2679$, $1706,1644,1550,1480,1427,1368,1316,1233,1110,1040,891 \mathrm{~cm}^{-1}$ NMR data: see Supporting Information; ESI-HRMS [M+H] ${ }^{+} \mathrm{m} / \mathrm{z} 568.1808$ (calcd for $\mathrm{C}_{29} \mathrm{H}_{30} \mathrm{O}_{11} \mathrm{~N}, 568.1813$ ).

For a complete summary of experimental and analytical details, see Supporting Information.

\section{Acknowledgements}

We are grateful for financial support from the Daimler Benz foundation to $\mathrm{CB}$ and the Villum Kann Rasmussen Foundation for a Young Investigator Fellowship (VKR10101) to MP. RB is generously supported by the International Leibniz Research School for Microbial and Biomolecular Interactions (ILRS) and School for Microbial Communication (JSMC, DFG). We thank Mrs. Heike Heinecke for recording NMR spectra, Mrs. Andrea Perner for HRMS measurements, Prof. Helge Bode for his valuable suggestions, and the Oerlemans family (Mookgophong) for permission to sample the colony.

Keywords: polyketides • natural products • tropolones • biosynthesis• chemical probe

[1] a) B. C. Covington, J. A. McLean, B. O. Bachmann, Nat. Prod. Rep. 2017, 34, 6; b) C. Kuhlisch, G. Pohnert, Nat. Prod. Rep. 2015, 32, 937.

[2] a) N. Ziemert, M. Alanjary, T. Weber, T. Nat. Prod. Rep., 2016, 33, 988; b) C. A. Dejong, G. M. Chen, H. Li, C. W. Johnston, M. R. Edwards, P. N. Rees, M. A. Skinnider, A. L. H. Webster, N. A. Magarvey, Nat. Chem. Biol. 2016, 12, 1007

[3] M. G. Moloney, Trends Pharmacol. Sci. 2016, 37, 689.

[4] a) O. Tyc, C. Song, J. S. Dickschat, M. Vos, P. Garbeva, Trends Microbiol. 2017, 25, 280; b) D. Romero, M. F. Traxler, D. López, R. Kolter, Chem. Rev. 2011, 111, 5492.

[5] a) C. Beemelmanns, H. Guo, M. Rischer, M. Poulsen, Beilstein J. Org Chem. 2016, 12, 314; b) T. R. Ramadhar, C. Beemelmanns, C. R. Currie, J. Clardy, J. Antibiot. 2014, 67, 53; c) M. Kaltenpoth, Trends Microbiol. 2009, 17, 529; d) H. B. Bode, Angew. Chem., Int. Ed. 2009, 48, 6394

[6] D. Oh, M. Poulsen, C. R. Currie, J. Clardy, J. Nature Chem. Bio. 2009, $5,391$.

[7] D. Oh, J. J. Scott, C. R. Currie, J. Clardy, Org. Lett. 2009, 11, 633.

[8] J. A. Blodgett, D. Oh, S. Cao, C. R. Currie, R. Kolter, J. Clardy, Proc. Natl. Acad. Sci. U. S. A. 2010, 107, 11692.

[9] A. A. Visser, T. Nobre, C. R. Currie, D. K. Aanen, M. Poulsen, Microb. Ecol. 2012, 63, 975.

[10] S. Um, A. Fraimout, P. Sapountzis, D. Oh, M. Poulsen, Sci. Rep. 2013, 3,3250 .
[11] G. Carr, M. Poulsen, J. L. Klassen, Y. Hou, T. P. Wyche, T. S. Bugni, C. R. Currie, J. Clardy, Org. Lett., 2012, 14, 2822.

[12] K. H. Kim, T. R. Ramadhar, C. Bieemelmanns, S. Cao, M. Poulsen, C. R. Currie, J. Clardy, Chem. Sci. 2014, 5, 4333.

[13] C. Beemelmanns, T. Ramadhar, K. H. Kim, J. Klassen, S. Cao, T. Wyche, Y. Hou, M. Poulsen, T. Bugni, C. Currie, J. Clardy, Org. Lett. 2017, 19, 1000

[14] M. Poulsen, Environ. Microbiol. 2015, 17, 2562.

[15] a) P. J. Rutledge, G. L. Challis, Nature Rev. Microbiol. 2015, 13, 509; b) A. A. Brakhage, J. Schümann, S. Bergmann, K. Scherlach, V. Schroeckh, C. Hertweck, Prog. Drug Res. 2008, 66, 3.

[16] H. Laatsch, AntiBase 2014: The Natural Compound Identifer. ISBN 978-3-33841-2.

[17] http://www.cas.org/products/scifinder

[18] a) X. Cai, Y.-M. Shi, N. Pöhlmann, O. Revermann, I. Bahner, S. J. Pidot, F. Wesche, H. Lackner, C. Büchel, M. Kaiser, C. Richter, H. Schwalbe, T. P. Stinear, A. Zeeck, H. B. Bode, Angew. Chem. Int. Ed. 2017, 56, 4945; b) Y. Yan, J. Yang, Z. Yu, M. Yu, Y. Ma, L. Wang, C. Su, J. Luo, G. P. Horsman, S. Huang, Nat. Ciommun. 2016, 7, 13083; c) Y. Yan, Y. Ma, J. Yang, G. P. Horsman, D. Luo, X. Ji, S. Huang, Org. Lett. 2016, $18,1254$.

[19] R. Bentley, Nat. Prod. Rep. 2008, 25, 118.

[20] J. Jeon, L. Liao, H. Kim, C. J. Sim, D. Oh, K. Oh, J. Shin, J. Nat. Prod. 2013, 76, 1679

[21] J. Ma, R. S. Pawar, E. Grundiel, E. P. Mazzola, C. D. Ridge, T. Masaoka, S. F. J. Le Grice, J. Wilson, J. A. Beutler, A. J. Krynitsky, J. Nat. Prod. 2015, 78, 315.

[22] a) N. J. Palleroni, K. E. Reichelt, D. Müller, R. Epps, B. Tabenkin, D. N. Bull, W. Schüep, J. Berger, J. Antibiot. 1978, 31, 1218; b) W. Schüep, J. F. Blount, T. H. Williams, A. Stempel J. Antibiot. 1978, 31, 1226.

[23] A. Bankevich, S. Nurk, D. Antipov, A. A. Gurevich, M. Dvorkin, A. S. Kulikov, V. M. Lesin, S. I. Nikolenko, S. Pham, A. D. Prjibelski, A. V. Pyshkin, A. V. Sirotkin, N. Vyahhi, G. Tesler, M. A. Alekseyev, P. A. Pevzner, J. Comput. Biol. 2012, 19, 455.

[24] Whole Genome Shotgun project has been deposited at DDBJ/ENA/GenBank under the accession MTBP00000000. The version described in this paper is version MTBP01000000.

[25] T. Seemann, Bioinformatics 2014, 30, 2068.

[26] T. Weber, K. Blin, S. Duddela, D. Krug, H. U. Kim, R. Bruccoleri, S. Y. Lee, M. A. Fischbach, R. Müller, W. Wohlleben, R. Breitling, E. Takano, M. H. Medema, Nucleic Acids Res. 2015, 43, W237.

[27] a) Y. Inhashi, T. Shiraishi, K. Palm, Y. Takahashi, S. Ōmura, T. Kuzuyama, T. Nakashima, ChemBioChem 2016, 17, 1442; b) L. R. Pickens, W. Kim, P. Wang, H. Zhou, K. Watanabe, S. Gomi, Y. Tang, J. Am. Chem. Soc. 2009, 131, 17677.

[28] T. A. Hall, Nucl. Acids Symp. Ser. 1999, 41, 95.

[29] http://decipher.cee.wisc.edu/FindChimerasOutputs.html

[30] http://blast.ncbi.nlm.nih.gov/Blast.cgi

[31] A. M. Bolger, M. Lohse, B. Usadel, Bioinformatics 2014, 30, 2114.

[32] D. H. Parks, M. Imelfort, C. T. Skennerton, P. Hugenholtz, G. W. Tyson, Genome research 2015, 25, 1043i.

[33] Sheldrick, G. M. Acta Cryst. 2008, A46, 112. 


\section{FULL PAPER}

We report the discovery of six new highly substituted tropolone alkaloids, rubterolones $\mathrm{A}-\mathrm{F}$, from Actinomadura sp. 5-2, isolated from the gut of the fungus-growing termite Macrotermes natalensis. Rubterolones were identified using fungus-bacteria challenge assays and a HRMS-based dereplication strategy, and characterized by NMR and HRMS analyses and X-ray crystallography.

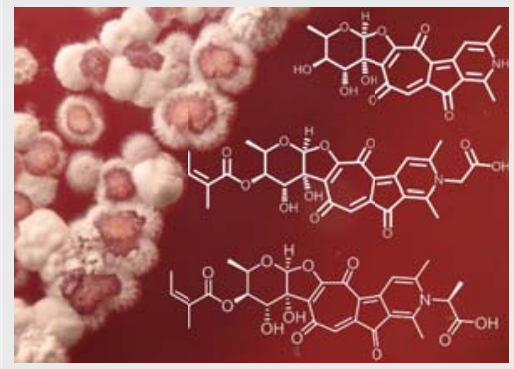

Huijuan Guı, René Benndorf, Daniel Leichnitz, Jonathan L. Klassen, John Vollmers, Helmar Görls, Matthias Steinacker, Christiane Weigel, HansMartin Dahse, Anne-Kristin Kaster, Wilhelm de Beer, Michael Poulsen, and Christine Beemelmanns*

Page No. - Page No.

Isolation, Biosynthesis and Chemical Modifications of Rubterolones A-F, Rare Tropolone Alkaloids from Actinomadura sp. 5-2 